\title{
PERIKANAN TERIPANG DI PERAIRAN KEPULAUAN SERIBU
}

\author{
Sri Turni Hartati", Indar Sri Wahyuni*), Suprapto*), dan Elly Reswati")
}

\begin{abstract}
ABSTRAK
Penelitian status perikanan teripang di perairan Kepulauan Seribu telah dilakukan pada musim peralihan barat ke timur, musim timur dan musim peralihan timur ke barat tahun 2001. Perairan Pulau Tikus dan Pulau Pramuka ditentukan sebagai lokasi penelitian. Tujuan dari penelitian adalah untuk memperoleh data dan informasi tentang stok teripang, lingkungan perairan teripang, dan aspek perikanan teripang lainnya. Data dan informasi tersebut diharapkan dapat digunakan sebagai data dasar dalam penentuan kebijakan pengelolaan sumber daya teripang yang lestari di perairan Kepulauan Seribu. Hasil penelitian menunjukkan bahwa di perairan Kepulauan Seribu terdapat 17 jenis teripang, 8 jenis diantaranya bernilai ekonomis dan 9 jenis lainnya tidak atau belum diusahakan. Kepadatan stok tertinggi di perairan P. Tikus terjadi pada musim timur, dengan kepadatan 0,189 ind $/ \mathrm{m}^{2}$ dan di perairan P. Pramuka pada musim peralihan barat ke timur, dengan kepadatan 0,084 ind $/ \mathrm{m}^{2}$. Kondisi lingkungan perairan masih dalam batas toleransi untuk kehidupan teripang, kecuali kecepatan arus yang relatif tinggi di perairan P. Pramuka terutama pada musim timur. Substrat dasar di perairan $P$. Tikus mempunyai ukuran partikel lebih halus dari pada di perairan $P$. Pramuka. Sebagian besar perairan di Kepulauan Seribu merupakan daerah penangkapan teripang, terutama di sekitar perairan Pulau Panggang. Hasil tangkapan mencapai $200 \mathrm{~kg}$ teripang kering/kapal/bulan. Pemasaran teripang hanya untuk ekspor, harga mencapai Rp. 600.000,-/kg di tingkat pengumpul untuk jenis teripang pasir (Holothuria scabra).
\end{abstract}

\section{ABSTRACT: Status of sea cucumber fisheries in Seribu Islands waters. By: Sri Turni Hartati, Indar Sri Wahyuni, Suprapto, and Elly Reswati}

Study on the status of sea cucumber fisheries in Seribu Islands was conducted in transitional west to east monsoon, east monsoon and transitional east to west monsoon in 2001. Two locations, Tikus Island and Pramuka Island were chosen, respectively. The aims of the study are to gather some data and information about sea cucumber stock in the study areas, environmental conditions of the sea cucumber habitat and other aspects of sea cucumber fisheries. Results obtained in this study would be used as a database supporting the sea cucumbers exploitation management in Seribu Islands. Results show that there are about 17 species of sea cucumbers in the study area, 8 species of these are valuable economically, while the remainder 9 species are not and have not been exploited. The highest density of sea cucumbers in the waters surrounding Tikus Island is attributable with a stock index of $0.189 \mathrm{ind} / \mathrm{m}^{2}$ and was found during the east monsoon. Meanwhile, in Pramuka Island waters, highest density was found to be $0.084 \mathrm{ind} / \mathrm{m}^{2}$ and occurred during the transitional west to east monsoon. The environmental conditions of the habitat in both areas are found to be in the range of tolerance for sea cucumbers, except for the current velocity that was relatively high in Pramuka Island, especially during the east monsoon. The particle size of the habitat substrate in Tikus Island is found to be smaller than that in Pramuka Island. Many parts of Seribu Islands waters are fishing ground for sea cucumbers, especially the waters surrounding Panggang Island. The average catch per unit effort reached about $200 \mathrm{~kg}$ of dried sea cucumbers/boat/month. Sea cucumbers in these areas are exploited mainly for export market, and at the collector level, for example, the price could fetch about Rp. 600.000,-/kg for sand fish (Holothuria scabra).

KEYWORDS: $\quad$ sea cucumbers, stock density, catch-per-unit effort of sea cucumbers, Seribu Islands

\section{PENDAHULUAN}

Secara geografis perairan Indonesia yang terletak di kawasan tropis kaya akan berbagai sumber daya ikan. Di antara yang bernilai ekonomis tinggi adalah teripang, yang dikenal juga sebagai ketimun laut atau "sea cucumber". Teripang dapat hidup beradaptasi dengan bermacam habitat seperti lumpur, pasir, batu karang, padang lamun, dan daerah pertumbuhan algae (Hyman, 1955). Penyebaran teripang di Indonesia yaitu di perairan Pulau Bangka, Pulau Belitung, Kepulauan Riau, Teluk Lampung, Kepulauan Seribu, NTT, NTB, Sulawesi, dan Kepulauan Maluku (Aziz, 1987).

\footnotetext{
Peneliti pada Balai Riset Perikanan Laut, Jakarta
} 
Tabel 1. Jenis-jenis teripang yang ditemukan di perairan Kepulauan Seribu pada tahun 2001 Table 1. Species of the sea cucumber found in Seribu Islands waters in 2001

\begin{tabular}{|c|c|c|c|}
\hline No. & $\begin{array}{c}\text { Jenis } \\
\text { (Species) }\end{array}$ & $\begin{array}{c}\text { Nama lokal } \\
\text { (Local name) }\end{array}$ & $\begin{array}{c}\text { Nama dalam bahasa Inggris } \\
\text { (English name) }\end{array}$ \\
\hline 1. & Holothuria scabra & teripang pasir & sandfish \\
\hline 2. & H. nobilis & teripang susuan & black teatfish \\
\hline 3. & H. atra & teripang keeling & lollyfish \\
\hline 4. & H. edulis & teripang dada merah & pinkfish \\
\hline 5. & H. impatiens & teripang oler & - \\
\hline 6. & H. pervicax & - & - \\
\hline 7. & H. fuscopunctata & - & - \\
\hline 8. & H. auricelsa & - & - \\
\hline 9. & H. hilla & - & - \\
\hline 10. & H. coronopertusa & - & - \\
\hline 11. & Stichopus variegatus & teripang gama & curryfish \\
\hline 12. & S. chloronatus & teripang nanas/bercak hitam & greenfish \\
\hline 13. & Actinopyga miliaris & teripang lotong & blackfish \\
\hline 14. & A. echinites & teripang bilalo & deep water redfish \\
\hline 15. & Bohadschia marmorata & teripang olok-olok & chalkyfish \\
\hline 16. & B. similis & - & - \\
\hline 17. & Synapta maculata & teripang sabuk raja & - \\
\hline
\end{tabular}

kepadatan stok teripang tertinggi terjadi pada musim timur, yaitu sebesar $0,189 \mathrm{ind} / \mathrm{m}^{2}$ yang terdiri dari sembilan jenis teripang. Jenis yang dominan di perairan $\mathrm{P}$. Tikus adalah Holothuria impatiens (teripang oler) dan Bohadschia marmorata (teripang olok-olok), dengan nilai kepadatan sama, yaitu masing-masing $0,06 \mathrm{ind} / \mathrm{m}^{2}$ dan kepadatan relatif $31,8 \%$. Tabel 3 menyajikan bahwa kepadatan stok teripang tertinggi di perairan $P$. Pramuka terjadi pada musim peralihan barat ke timur, yaitu sebesar 0,084 ind $/ \mathrm{m}^{2}$ yang terdiri dari 13 jenis. Jenis teripang yang dominan di perairan P. Pramuka adalah Synapta maculata (teripang sabuk raja) yang tidak bernilai ekonomis, dengan kepadatan $0,028 \mathrm{ind} / \mathrm{m}^{2}$ dan kepadatan relatif $33,3 \%$. Jenis yang bernilai ekonomis, seperti Stichopus variegatus, Holothuria nobilis, dan Holothuria atra kepadatannya relatif rendah, yaitu antara $0,001-0,007 \mathrm{ind} / \mathrm{m}^{2}$ dan kepadatan relatif antara $1,2 \%-8,3 \%$.

Hasil penelitian tersebut di atas menunjukkan bahwa stok teripang di perairan Kepulauan Seribu mengalami penurunan, sejak mulai diusahakan oleh nelayan pada tahun 1973. Pada tahun 1986 tingkat pengusahaan teripang sangat intensif, hasil tangkapan nelayan dapat mencapai 1.000 ekor dalam satu hari (Azkab \& Hutomo, 1986). Hasil penelitian terbaru (Teswara, 1995), kepadatan stok teripang di perairan Kepulauan Seribu berkisar antara $0,147-0,341 \mathrm{ind} / \mathrm{m}^{2}$.

Habitat atau tempat hidup teripang adalah ekosistem terumbu karang dan ekosistem lamun, mulai dari zona intertidal sampai kedalaman 20 meter. Pada umumnya teripang menyukai perairan yang bersih dan jernih dengan salinitas normal sekitar 30-33\%o, dasar berpasir halus (lamun), terlindung dari hempasan ombak, dan lingkungan hidupnya kaya akan kandungan detritus (Azis, 1999). Hasil pengamatan di P. Tikus dan P. Pramuka baik pada musim timur maupun kedua musim peralihan menunjukkan bahwa perairannya dalam kondisi cukup jernih. Di perairan P. Tikus kecerahannya mencapai dasar perairan dan di $P$. Pramuka kecerahannya mencapai 8-9 m. Kecepatan arus di P. Pramuka lebih tinggi dari pada di perairan $P$. Tikus terutama pada musim timur yang mencapai $65 \mathrm{~cm} /$ detik. Pada musim timur tersebut kelimpahan stok teripang di perairan $P$. Pramuka relatif rendah, yaitu $0,016 \mathrm{ind} / \mathrm{m}^{2}$ yang terdiri dari lima jenis teripang. Teripang didominasi jenis Synapta maculata (teripang sabuk raja), yang dapat mencengkram objek (karang tempat melekat) cukup sehingga tidak dipengaruhi oleh arus.

Nilai parameter lingkungan perairan lainnya adalah suhu berkisar antara $28,91^{\circ} \mathrm{C}-30,57^{\circ} \mathrm{C}$, $\mathrm{pH}$ berkisar antara 7,59 - 8,16, salinitas berkisar antara 32-33\%o, dan oksigen terlarut berkisar antara 5,9 - 7,10 mg/lt. Perairan P. Tikus dan P. Pramuka adalah merupakan perairan karang, sehingga kepadatan fitoplankton dan zooplanktonnya relatif rendah. Kepadatan fitoplankton berkisar antara 23,732 - 96,820 sel// ${ }^{3}$ dan zooplankton berkisar antara 1,716 - 7,279 ind $/ \mathrm{m}^{3}$. Kondisi lingkungan perairan tersebut masih dalam batas toleransi untuk kehidupan teripang. Bakus (1973) menyatakan bahwa teripang 


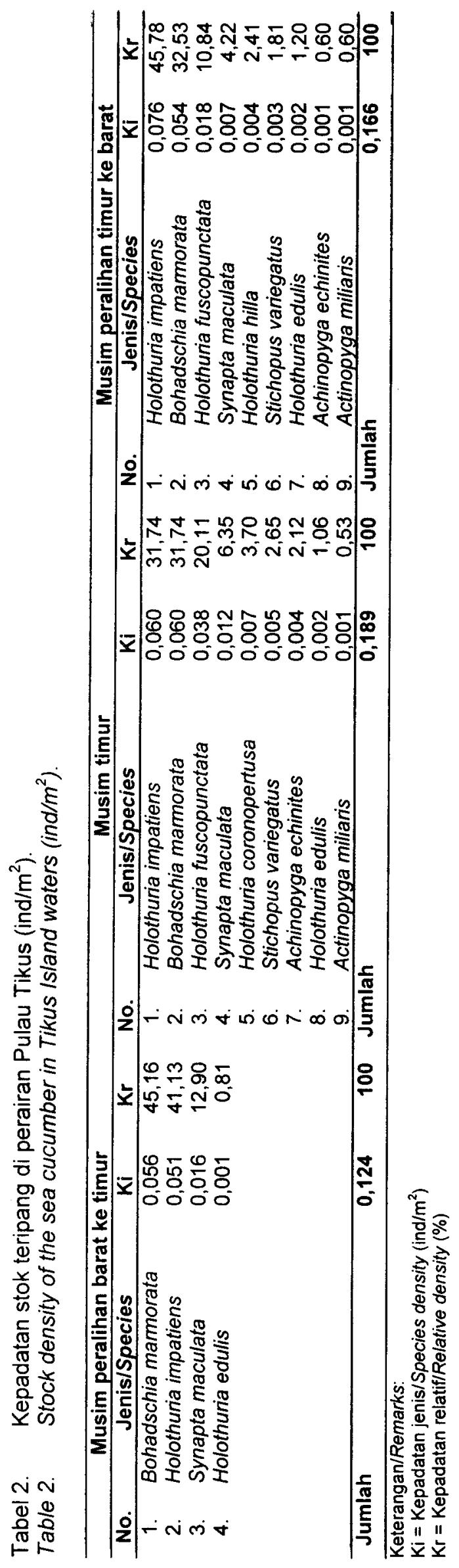




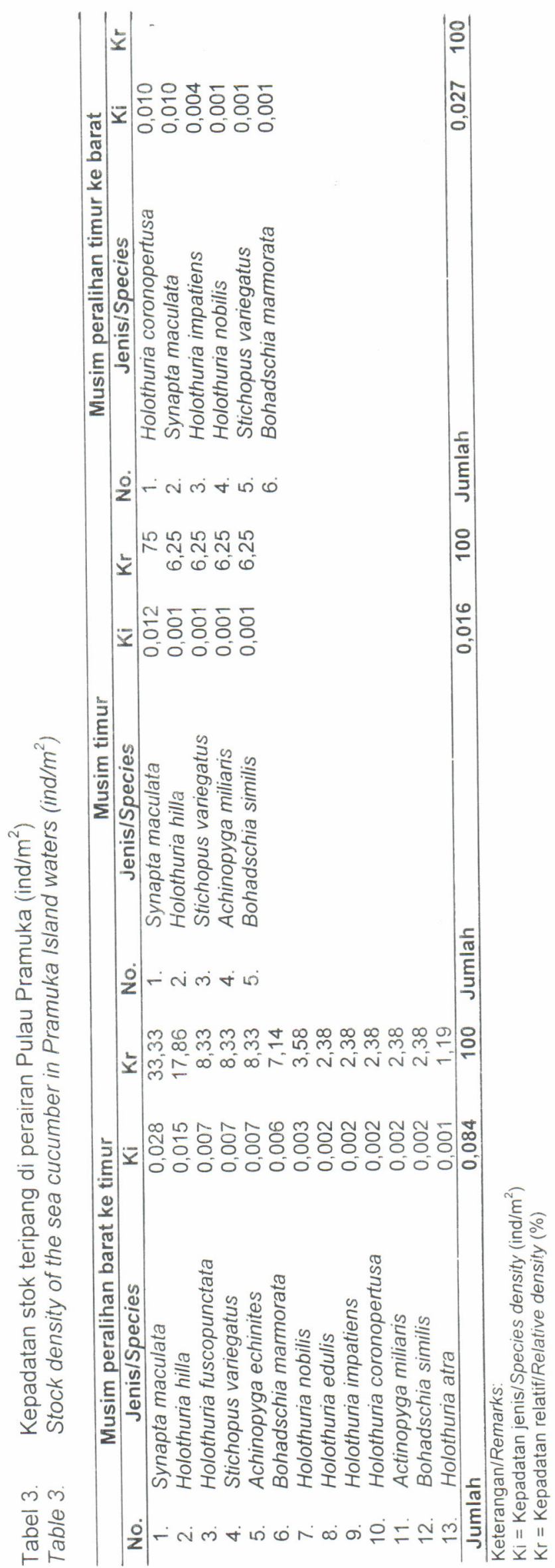


Tabel 4. Kondisi lingkungan perairan teripang di perairan Pulau Tikus

Table 4 Environment condition of the sea cucumber habitat in Tikus Island

\begin{tabular}{lccc}
\hline Parameter/Parameters & $\begin{array}{c}\text { M. Peralihan barat } \\
\text { ke timur }\end{array}$ & M. Timur & $\begin{array}{c}\text { M. Peralihan timur } \\
\text { ke barat }\end{array}$ \\
\hline - Kedalaman/Depth $(\mathrm{m})$ & $0,8-1,2$ & $0,8-1,2$ & $0,8-1,2$ \\
- Kecerahan/Transparancy $(\mathrm{m})$ & sampai dasar & sampai dasar & sampai dasar \\
- suhu/Temperature $\left({ }^{\circ} \mathrm{C}\right)$ & 30,57 & 29,66 & 30,28 \\
- pH & 7,94 & 8,03 & 8,16 \\
- Salinitas/Salinity $(\%)$ & 33 & 33 & 32 \\
- Oksigen terlarut/DO $(\mathrm{mg} / \mathrm{l})$ & 6,24 & 7,10 & 6,84 \\
- Kec. arus/Current $(\mathrm{cm} / \mathrm{det})$ & tdk. terdeteksi & tdk. terdeteksi & tdk. terdeteksi \\
- Phytoplankton $\left(\mathrm{cells} / \mathrm{m}^{3}\right)$ & 23,732 & 24,126 & 77,316 \\
- Zooplankton $($ ind $/ \mathrm{m} 3)$ & 3,146 & 7,279 & 1,716 \\
\hline
\end{tabular}

Tabel 5. Kondisi lingkungan perairan teripang di perairan Pulau Pramuka

Table 5. Water environment condition of the sea cucumber habitat in Pramuka Island

\begin{tabular}{lccc}
\hline Parameter/Parameters & $\begin{array}{c}\text { M. Peralihan barat } \\
\text { ke timur }\end{array}$ & M. Timur & $\begin{array}{c}\text { M. Peralihan timur } \\
\text { ke barat }\end{array}$ \\
\hline - Kedalaman/Depth $(\mathrm{m})$ & $3,5-11$ & $3,5-11$ & $3,5-11$ \\
- Kecerahan/Transparancy $(\mathrm{m})$ & 9,0 & 9,0 & 8,0 \\
- suhu/Temperature $\left({ }^{\circ} \mathrm{C}\right)$ & 29,80 & 28,91 & 29,17 \\
- pH & 7,59 & 7,82 & 8,0 \\
- Salinitas/Salinity $(\% \circ)$ & 32 & 33 & 32,5 \\
- Oksigen terlarut/DO $(\mathrm{mg} / \mathrm{l})$ & 5,9 & 7,0 & 6,46 \\
- Kec. arus/Current $(\mathrm{cm} / \mathrm{det})$ & 30 & 65 & 35 \\
- Phytoplankton $\left(\mathrm{cells} / \mathrm{m}^{3}\right)$ & 77,316 & 81,572 & 96,820 \\
- Zooplankton $($ ind/m3) & 2,752 & 4,250 & 4,584 \\
\hline
\end{tabular}

mempunyai batas toleransi terhadap suhu antara $26-31^{\circ} \mathrm{C}$. Menurut Pawson (1970), teripang menempati perairan yang mempunyai salinitas normal dan tidak toleran terhadap salinitas rendah. Secara umum semua fauna Echinodermata merupakan hewan yang tidak toleran terhadap salinitas rendah, tetapi diantara semua jenis Echinodermata teripang adalah yang paling tidak toleran. Dikemukakan oleh Ong Che (1990) bahwa pada daerah tropis di mana suhu perairan hampir tidak berubah sepanjang tahun, peranan salinitas dalam pengaturan reproduksi mungkin lebih penting dibanding suhu. Kandungan oksigen terlarut yang layak bagi kehidupan teripang yaitu 4 - 8 ppm (Panggabean, 1987), sedangkan tempat ditemukannya teripang di perairan alami berkisar antara 5,63-6,94 ppm (Alwi, 1995).

\section{Substrat Dasar Perairan}

Pengamatan substrat dasar perairan dibedakan atas tujuh ukuran partikel, yaitu dari endapan/debu kasar berukuran $0-0,075 \mathrm{~mm}$ sampai dengan pasir kasar sekali berukuran $2 \mathrm{~mm}$. Substrat dasar perairan di P. Pramuka didominasi oleh partikel pasir kasar sekali berukuran $1 \mathrm{~mm}$ yaitu sebanyak $39,44 \%$, kemudian disusul oleh partikel kasar
$22,93 \%$, pasir agak kasar berukuran $0,5 \mathrm{~mm}$ sebanyak $15,76 \%$, pasir sedang berukuran 0,25 $\mathrm{mm}$ sebanyak $9,72 \%$, pasir halus berukuran 0,14 $\mathrm{mm}$ sebanyak $6,44 \%$, pasir halus sekali berukuran 0,075 sebanyak $3,58 \%$, dan endapan/debu kasar sebanyak $2,14 \%$.

Substrat dasar perairan di P. Tikus mempunyai ukuran partikel lebih halus dibandingkan dengan di perairan P. Pramuka. Ukuran partikel substrat dasar perairan di P. Tikus di dominasi oleh pasir sedang sebanyak $25,20 \%$, kemudian pasir kasar sebanyak $21,08 \%$, pasir agak kasar sebanyak $18,47 \%$, pasir kasar sekali sebanyak $14,26 \%$, pasir halus sebanyak $14,08 \%$, pasir halus sekal! sebanyak 5,92\%, dan endapan/debu kasar sebanyak 0,99\%. Persentase ukuran partikel substrat dasar perairan di Pulau Tikus dan Pulau Pramuka disajikan pada Gambar 2

Wood (1987) menyatakan bahwa terdapat hubungan antara kandungan bahan organik dengan ukuran partikel sedimen. Pada sedimen yang halus, persentase bahan organik lebih tinggi dibandingkan pada sedimen yang kasar, hal ini berhubungan dengan kondisi lingkungan yang tenang sehingga memungkinkan pengendapan 


\section{P. Tikus}

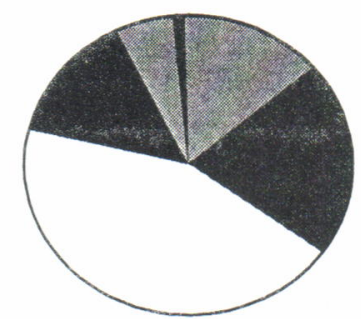

P. Pramuka

pasir kasar sekali $(2 \mathrm{~mm})$

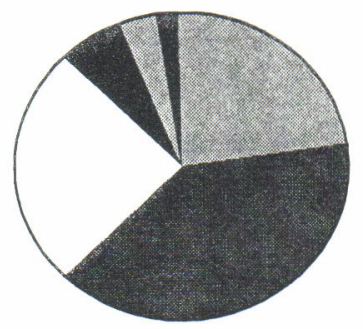

-pasir kasar (1 mm)

$\square$ pasir agak kasar $(0.5 \mathrm{~mm})$

口pasir sedang $(0.25 \mathrm{~mm})$

pasir halus $(0.149 \mathrm{~mm})$

pasir halus sekali $(0.075 \mathrm{~mm})$

endapan/debu kasar $(0-0.075 \mathrm{~mm}$

Gambar 2. Persentase ukuran partikel substrat perairan di Pulau Tikus dan Pulau Pramuka. Figure 2. Precentage of the size of substrat particles in Tikus and Pramuka Islands waters.

sedimen lumpur yang diikuti oleh akumulasi bahan organik ke dasar perairan. Sedangkan pada sedimen yang kasar, kandungan bahan organiknya lebih rendah karena partikel yang lebih halus tidak mengendap sebagai akibat arus yang relatif deras.

\section{Aspek Perikanan}

\section{Alat, cara dan daerah penangkapan}

Penangkapan teripang di Kepulauan Seribu dilakukan dengan menggunakan dua cara yaitu dengan menggunakan kompresor dan petromak. Kegiatan penangkapan dengan menggunakan petromak lamanya satu hari (one day fishing). Penangkapan dilakukan sekitar jam 16.00-24.00, pada waktu surut di perairan yang dangkal. Kegiatan penangkapan dengan menggunakan kompresor lamanya satu minggu - satu bulan per tripnya. Penangkapan dengan kompresor dilakukan pada siang hari dan malam hari. Pada siang hari dilakukan jam 07.00-15.00 dan pada malam hari dilakukan pada jam 19.00-23.00 Penangkapan dilakukan dengan menyelam sehingga dapat mencapai perairan yang dalam.

Daerah penangkapan teripang di Kepulauan Seribu antara lain di Pulau Bidadari, P. Dua, P. Edam, P. Bokor, P. Karang Songka, P. Kelapa, P. Karang Beras, P. Semak Daun, P. Putri, P. Panggang, P. Kelor, P. Bira, P. Pramuka, P. Gosong, P. Karang Lebar, P. Air, P. Opak Besar,
P. Opak Kecil, P. Semut, P. Panjang, P. Belanda P. Kuburan Cina, P. Genteng, P. Kayu Angin Bira Besar, P. Kayu Angin Bira Kecil, P. Pamagaran, dan beberapa pulau lainnya.

\section{Hasil tangkapan}

Hasil tangkapan dari kegiatan sehari (one day fishing) sekitar 8-10 kg teripang kering, sedangkan yang menggunakan kompresor dalam waktu satu minggu diperoleh hasil sekitar $30-60 \mathrm{~kg}$ teripang kering. Selain nelayan lokal ada juga nelayan pendatang dari Madura, yang berkeliling di Kepulauan Seribu, terutama di sekitar perairan $P$. Panggang selama tiga minggu sampai satu bulan diperoleh hasil sekitar $60-200 \mathrm{~kg}$ teripang kering.

\section{Pengolahan}

Pengolahan teripang basah menjadi kering pada umumnya sama untuk semua jenis, yaitu setelah dibuang kotorannya, kemudian direbus, diasap, dan dikeringkan. Pengecualian untuk jenis teripang pasir, yaitu setelah direbus, kemudian digosok dengan menggunakan daun pepaya atau dikerik untuk mengeluarkan kapur. Proses selanjutnya direbus kembali baru kemudian diasap dan dikeringkan.

\section{Pemasaran}

Salah satu aspek dari kegiatan ekonomi adalah pemasaran. Pada prinsipnya pemasaran merupakan aliran dari produsen ke konsumen. 
Aliran barang ini akan terjadi karena adanya peranan lembaga pemasaran yang sangat tergantung pada sistem pasar yang berlaku dan karakteristik aliran barang yang dipasarkan. Kegiatan ini juga berlaku pada komoditi hasil perikanan, bahkan peranan lembaga pemasaran sangat vital dan menentukan terhadap harga yang ditawarkan. Hal ini disebabkan karena lembaga pemasaran ini mempunyai posisi tawar menawar (bargaining position) yang lebih kuat dibandingkan dengan nelayan sebagai produsen. Kegiatan pemasaran teripang merupakan jembatan antara nelayan sebagai produsen dengan berbagai tingkat pedagang teripang. Jalur tata niaga teripang di Kepulauan Seribu disajikan pada skema Gambar 3.

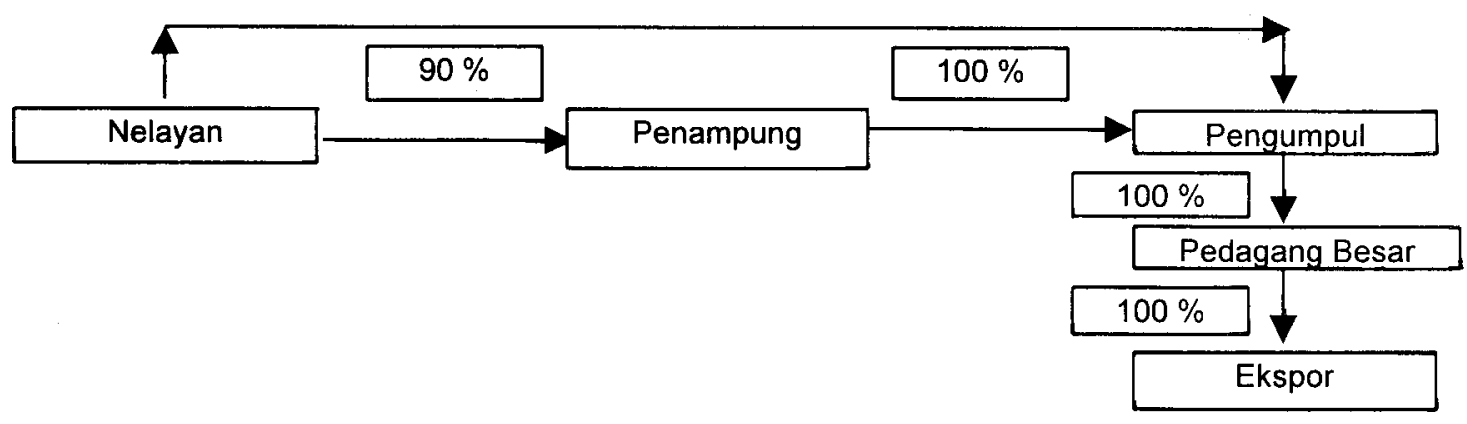

Gambar 3. Skema tata niaga teripang di Kepulauan Seribu.

Figure 3. Flowchart of market distribution of sea cucumbers in Seribu Islands.

Tata niaga teripang ditingkat produsen sebagian besar dijual melalui penampung kemudian dari penampung dijual ke pengumpul dan dari pengumpul dijual ke pedagang besar yang ada di Jakarta dan Surabaya selanjutnya untuk diekspor ke Amerika, Thailand, dan Singapura. Berdasarkan pengamatan di lapangan, nelayan di P. Pramuka selain sebagai penangkap teripang juga sebagai pengolah dan menjual hasil tangkapan dalam bentuk olahan (kering). Sedangkan nelayan di $P$. Panggang sebagian menjual dalam bentuk segar/basah dan sebagian dalam bentuk olahan (kering). Diperkirakan 10\% nelayan teripang menjual hasil tangkapannya ke pengumpul dan $90 \%$ melalui penampung.

Pemasaran teripang di Kep. Seribu sangat bagus. Harga relatif tinggi, untuk jenis Holothuria scabra (teripang pasir) dapat mencapai harga Rp. $300.000 / \mathrm{kg}$ di tingkat nelayan dan Rp.600.000/kg di tingkat pengumpul. Informasi tentang jenis-jenis teripang yang diusahakan beserta harganya disajikan pada Tabel 6 .

Tabel 6. Jenis-jenis teripang yang diusahakan di Kepulauan Seribu

Table 6. Species of the sea cucumber exploited in Seribu Islands

\begin{tabular}{lrr}
\hline Jenis teripang/Species & $\begin{array}{c}\text { Harga nelayan per } \mathbf{k g} \\
\text { (Price in fisherman per } \mathbf{k g})\end{array}$ & $\begin{array}{c}\text { Harga penampung per } \mathbf{k g}(\mathbf{R p}) \\
\text { (Price in collector per } \mathbf{k g})\end{array}$ \\
\hline - Teripang pasir & 300.000 & 600.000 \\
- Teripang gama & & \\
Super $(20 \mathrm{~cm})$ & 120.000 & 150.000 \\
Tanggung $(15 \mathrm{~cm})$ & 90.000 & 105.000 \\
Kacang $(10 \mathrm{~cm})$ & 45.000 & 60.000 \\
- Teripang nanas & 120.000 & 150.000 \\
- Teripang olok-olok & 8.500 & 10.500 \\
- Teripang bilalo & 120.000 & 150.000 \\
\hline
\end{tabular}

\section{KESIMPULAN}

1. Sumber daya teripang di perairan Kepulauan Seribu sekurang kurangnya ada tujuh belas jenis, delapan jenis bernilai ekonomis dan sembilan jenis lainnya tidak atau belum diusahakan. Kepadatan stok teripang tertinggi di perairan Pulau Tikus terjadi pada waktu musim timur, yaitu 0.189 ind $/ \mathrm{m}^{2}$ dan di perairan Pulau Pramuka terjadi pada waktu musim peralihan barat ke timur, yaitu $0.084 \mathrm{ind} / \mathrm{m}^{2}$.

2. Kisaran nilai parameter lingkungan perairan di Kepulauan Seribu adalah suhu berkisar antara 
28.91-30.57 ${ }^{\circ} \mathrm{C}, \mathrm{pH}$ berkisar antara 7.59-8.16, salinitas berkisar antara $32-33 \%$ oksigen terlarut berkisar antara 5.9-7.10 mg/lt, kepadatan fitoplankton berkisar antara 23.732$96.820 \mathrm{sel} / \mathrm{m}^{3}$, dan kepadatan zooplankton berkisar antara 1.716-7.279 ind $/ \mathrm{m}^{3}$. Kecepatan arus tidak terdeteksi di perairan P. Tikus, sedangkan di perairan $P$. Pramuka relatif kencang, yaitu $65 \mathrm{~cm} /$ detik pada musim timur. Substrat dasar perairan di perairan $P$. Tikus mempunyai ukuran partikel lebih halus dari pada di perairan $P$. Pramuka.

3. Hampir sebagian besar perairan di Kepulauan Seribu merupakan daerah penangkapan teripang, terutama di perairan $\mathrm{P}$. Panggang dan sekitarnya. Hasil tangkapan nelayan mencapai $200 \mathrm{~kg}$ teripang kering/kapal/bulan. Pemasaran teripang di Kepulauan Seribu hanya untuk ekspor melalui pedagang besar di Jakarta dan Surabaya. Harga relatif tinggi, dapat mencapai Rp. $600.000 / \mathrm{kg}$ di tingkat pengumpul untuk jenis yang bernilai ekonomis tinggi.

\section{DAFTAR PUSTAKA}

Alwi, W. 1995. Beberapa aspek biologi reproduksi dan kualitas habitat teripang pasir (Holothuria scabra) ekonomis yang dieksploitasi di perairan Teluk Lampung. Skripsi Fakultas Perikanan IPB. Bogor. 58 hal

Azis, A. 1987. Beberapa catatan tentang perikanan teripang di Indonesia dan kawasan Indo Pasifik Barat. Oseana XII (2). Hal: 68--78.

Azis, A. 1999. Status penelitian teripang komersial di Indonesia. Prosiding Seminar tentang Oseanologi dan IImu Lingkungan Laut. Puslitbang Oseanologi. LIPI. Jakarta. Hal: 221 232.

Azkab, H. M. \& M. Hutomo. 1986. Sumber daya Kepulauan Seribu dan peranan stasiun penelitian oseanologi Pulau Pari. Oseana (XI) 2: 45 .

Bakus. 1973. The biologi and ecologi of tropical holothurians. In: O.A. Jones \& R. Endean (eds), Biology and Geology of Coral Reef. Vol. II.
Biology I. Academic Press. New York. Hal: 325367

Cox, G.W. 1967. Laboratory manual of general ecology. M.W.C. Brown Co. Publ., Dubuque, lowa. Hal: 35.

Ditjen Perikanan. 1988. Statistik ekspor dan impor hasil perikanan. Direktorat Jenderal Perikanan. Departemen Pertanian. Jakarta. 50 hal.

Ditjen Perikanan. 1995. Statistik ekspor dan impor hasil perikanan. Direktorat Jenderal Perikanan. Departemen Pertanian. Jakarta. 170 hal.

Hyman. 1955. The invertebrates: Echinodermata, the coelomata bilateria. Mc Graw Hill Co. Inc New York. Vol IV. Hal: 121

Hashimoto, Y. 1979. Marine toxins and other bioactive marine metabolites. Japan Scienyific Societies Press, Tokyo.

Martoyo, J., N. Aji dan T. Ulinanto. 1994. Budi daya teripang. Penebar Swadaya. Hal: 1

Ong Che, R.G. 1990. Aspects of the feeding biology of Holothuria leucospilota Brandt (echinodermata: holothuroidea) in Hongkong Asian Marine Biol. 7. Hal: 133--146.

Panggabean, T.M. 1987. Budi daya teripang/ketimun laut dalam rangka meningkatkan produksi hasil laut di Indonesia. Ditjen Perikanan bekerja sama dengan International Development Research Center. INFIS Manual No.44.

Pawson, D.L. 1970. The marine fauna of New Zealand: sea cucumbers (Echinodermata: Holothuroidea). Bull. N.Z. Dept. Scient. Ind. Res. 201. New Zealand. 69 hal

Teswara, A. 1995. Perbandingan komposisi jenisjenis teripang (holothurioidea) di P. Kayu Angin Bira dan P. Pramuka. Taman Nasional Laut Pulau-Pulau Seribu, Jakarta. Universitas Nasional. Jakarta. 55 hal.

Wood, M.S. 1987. Subtidal ecology. Edward Arnold. Dty. Limited. Australia. 465 hal. 